\title{
Ultrasound evaluation on carpal tunnel syndrome before and after bariatric surgery
}

\section{Avaliação ultrassonográfica da síndrome do túnel do carpo antes e após cirurgia bariátrica}

Adham do Amaral e Castro ${ }^{1,3}$; Thelma larocca Skare ${ }^{1,4}$; Paulo Afonso Nunes Nassif ${ }^{1,2}$; Alexandre Kaue Sakuma ; Bruno luiz Ariede ${ }^{1}$; Wagner Haese Barros 3

\section{A}

\begin{abstract}
Objective: To evaluate the prevalence of carpal tunnel syndrome in candidates for bariatric surgery comparing with the non-obese population and verify the effects on it of bariatric treatment. Methods: We studied three groups of individuals: 1) patients waiting for bariatric surgery (preoperative); 2) individuals who had already undergone the procedure (postoperative); and 3) control group. We collected demographic and clinical data of carpal tunnel syndrome. The Ultrasound examination was carried out to diagnose the syndrome by measuring the median nerve area. Results: We included 329 individuals (114 in the preoperative group, 90 in the postoperative group and 125 controls). There was a higher prevalence of paresthesias $(p=0.0003)$, clinical tests $(p=0.0083)$ on the preoperative group when compared with controls $(p<0.00001)$. There were lowe levels of paresthesias $(p=0.0002)$ and median nerve area $(p=0.04)$ in postoperative patients but with no significant difference in general. A significant difference was found between the preoperative and postoperative groups $(p=0.05)$ in those who performed non-manual work. Conclusion: There was a higher prevalence of carpal tunnel syndrome in the preoperative group compared with the control one, but no significant difference was observed between the pre and postoperative groups in general. There was difference between pre and postoperative groups for non-manual workers.
\end{abstract}

Key words: Obesity. Carpal tunnel syndrome. Ultrasound. Bariatric surgery.

\section{INTRODUCTION}

C arpal tunnel syndrome (CTS) is the most common entrapment neuropathy and one of the most common peripheral neuropathies ${ }^{1,2}$. Although its cause is unknown, there are conditions associated with it, such as obesity, pregnancy, diabetes mellitus, wrist repetitive stress and hypothyroidism. CTS diagnosis is primarily based on clinical history of pain and paresthesia along the median nerve distribution, and on physical examination ${ }^{1,2}$.

Symptoms severity and functional impairment are the main concerns of patients. Aiming to quantify these problems, Levine et al. ${ }^{3}$ developed a specific questionnaire known as Boston Carpal Tunnel Questionnaire (BCTQ) that is a valid, reliable and well accepted tool for the quantification of symptoms and functional damage associated with $\mathrm{CTS}^{4,5}$.

The most widely accepted theories for CTS ethiopathology are the mechanical and the microvascular nerve damage ${ }^{2}$. Many authors considered obesity as a predisposing factor ${ }^{6-13}$, as it may be associated to the mechanical theory when the fat tissue causes nerve root compression and raises local hydrostatic pressure ${ }^{10,12}$. However, microvascular insufficiency secondary to atherosclerosis, which is more common in the obese population ${ }^{13}$, may also play a role.

The diagnosis is mainly clinical, but it can be corroborated by the electromyography and imaging exams, specially magnetic resonance imaging and ultrasonography (US), which has the advantage of being rapidly done, accessible and cheap ${ }^{14}$. With the advent of high-frequency transducers there has been great improvement in imaging of superficial structures, such as those in the hand and wrist. The median nerve is easily detectable ${ }^{15}$. For the US diagnosis of CTS the most important criteria is the cross sectional area of the median nerve $(\mathrm{MNA})^{16}$. In addition to diagnosis, US can provide information about CTS causes and it can be a reliable method for treatment follow-up, as it can be easily repeated 17 .

This paper aims to verify the prevalence of CTS in obese patients candidates for bariatric surgery, comparing them with non obese individuals and with patients that

1. Postgraduate Program, Principles of Surgery, Evangelical School of Paraná / Evangelical University Hospital of Curitiba / Institute for Medical Research, Curitiba, Paraná State - PR, Brazil; 2. Bariatric and Metabolic Surgery, Evangelical University Hospital of Curitiba; 3. Diagnostic Imaging Service, Evangelical University Hospital of Curitiba; 4. Rheumatology Service, Evangelical University Hospital of Curitiba. 
have already undergone bariatric surgery, to verify if weight loss affected prevalence and severity of the symptoms.

\section{METHODS}

This study was approved by the local Ethics in Research Committee and all participants signed an informed consent. This was an observational, cross-sectional, casecontrol study conducted in the Outpatient Clinic of the Department of Metabolic and Bariatric Surgery and in the Image Diagnosis Service of Evangelic University Hospital of Curitiba, PR, Brazil. The inclusion period went from October 2012 to October 2013.

We studied three groups of patients: 1) obese candidates for bariatric surgery (preoperative group); 2) patients who had already undergone bariatric surgery (postoperative group); and 3) control group. The inclusion of pre and postoperative patients was done according to consultation order and willingness to participate in this study. This was a convenience sample. To be included, patients had to be more than 18 years old. We excluded pregnant women, patients with untreated hypothyroidism, chronic kidney disease on dialysis, history of repetitive stress injuries, recent trauma in the upper limbs and any form of arthritis.

The control group consisted of volunteers randomly approached inside the hospital (mostly patients of ophthalmology and gynecology clinic and hospital staff) matched for age and gender, type of occupation (manual vs. non-manual) and ethnicity; we applied the same inclusion and exclusion criteria to patients of the preoperative group.

After demographic data collection that included information on occupational activities, all individuals were invited to fill in a Katz diagram ${ }^{18}$ about pain and numbness in the median nerve distribution (or palmar surface of the $1^{\text {st }}, 2^{\text {nd }}$ and $3^{\text {rd }}$ fingers and radial half of the $4^{\text {th }}$ finger) and to answer the $\mathrm{BCTQ}^{4}$. All groups were submitted to measurement of weight and height for body mass index (BMI) calculation ${ }^{19}$ and we considered obesity when the BMI was e" 30( kg/m2 $)^{19}$.

We performed the Tinel maneuver by tapping the median nerve at the distal wrist level for about 10 seconds, and we considered it positive with the reproducibility of pain or numbness in the distribution of the corresponding median nerve ${ }^{20}$. We performed the Phalen's maneuver by bending both hands $90^{\circ}$, with their backs in opposition to each other for at least $1 \mathrm{~min}$, being positive when triggering pain or tingling in the median nerve distribution ${ }^{20}$.

We used the translated and validated BCQT version for Brazilian Portuguese ${ }^{4}$. It measures two different domains. The first is symptoms severity and has 11 questions graded by a Likert scale, which ranges from 1 to 5 points per item. The second refers to patient's functional status and contains eight items, graduated in 1 to 5 points, which measures the ability to perform a given task using the hands. Higher BCTQ scores are associated to higher symptom's severity and higher functional disability ${ }^{5}$.

The wrist US was performed by a blind physician using a Toshiba ${ }^{\odot}$ system Xario $^{\odot}$ device, with the $12 \mathrm{MHz}$ multifrequency linear transducer. To perform the test, the patient was seated with the forearm in supine resting on a table, wrist in neutral position and with semi-inflected fingers. The measurement of the nerve was performed with the transducer being positioned at the level of the distal volar surface of the wrist to the pisiform bone and the scaphoid bone tuberculum level. Cross-sectional images of the wrist were obtained by evaluating the MNA, drawing a continuous line around the edge of the nerve ${ }^{21}$. MNA e" 9 $\mathrm{mm}^{2}$ was considered diagnostic of CTS ${ }^{16}$. As MNA of both hands were measured, for statistical purpose we considered the one with highest value.

We collected data in frequency and contingency tables. Categorical variables were expressed as percentages. For measures of central tendency of parametric numerical variables, we used the mean and standard deviation. For non-parametric variables we used the median and interquartile range (IQR). We studied the normality of data distribution by the Kolmogorov-Smirnov test. We performed the comparison of nominal variables with the Fisher's and chi square tests. For comparison of two numeric variables we used the unpaired t test for the parametric ones and the Mann-Whitney test for the nonparametric ones. We performed correlation analyses with the Spearman tests. We used the Graph Pad Prism version 4.0 software for calculations, and adopted the significance level of $5 \%$.

\section{RESULTS}

\section{Descriptive analysis of the studied sample}

Were included a total of 329 individuals: 114 patients were in the preoperative group; 90 in the postoperative group; and 125 in the control group

The control group consisted of 15 (12.8\%) men and $109(87.2 \%)$ women, aged 23-65 years (mean $40.27 \pm 10.26)$. The $\mathrm{BMI}$ in controls ranged from 17.57 to $33.05 \mathrm{~kg} / \mathrm{m}^{2}$ (median 26.6; IQR $=22.9-28.7$ ). In the preoperative group there were $11(9.6 \%)$ males and 103 (90.3\%) females, aged between 18 and 66 years (mean $40.86 \pm 11.17)$. The BMI of these patients ranged from 34.5 to $72.31 \mathrm{~kg} / \mathrm{m}^{2}$ (median $42.48, \mathrm{IQR}=40.0$ to 46.03 ). In the postoperative group there were $8(8.8 \%)$ men and 81 (91.2\%) women, aged 22 to 59 years (mean $42.00 \pm 10.05$ ) with BMl between 20.54 and $43.73 \mathrm{~kg} / \mathrm{m}^{2}$ (median 28.47, IQR 25.15 to 31.69).

In the sample of postoperative patients the weight (in $\mathrm{kg}$ ) lost after surgery ranged from 4.0 to 130.0 (mean $39.09 \pm 17.39$ ) and the number of days after surgery in this group patients ranged from nine to 4745 (median 405; IQR 181.5 to 675$)$. 
The comparison between preoperative and postoperative individuals is in table 1 , in which it can be observed that the only difference between groups is the BMI, as would be expected.

The prevalence of CTS symptoms and signals and MNA measures in each group are shown in table 2.

\section{Study on correlation of CTS severity, BMI and MNA measured by US}

When studying the correlation between the severity of CTS measured by the BCTQ and the largest MNA in the 329 individuals included in the study, we found a positive correlation, with $\mathrm{p}<0.0001$ (Spearman's Rho $=0.44 ; 95 \% \mathrm{Cl}=0.34-0.52$ ). When analyzing the correlation between disease severity measured by the BCQT with the BMI in these same individuals, we found a positive correlation, with $\mathrm{p}<0.0001$ (Spearman's Rho $=0.28 ; 95 \% \mathrm{Cl}=0.17-0.38$ ). We also observed a positive correlation between $\mathrm{BMI}$ and MNA, with $\mathrm{p}<0.001$ (Spearman's Rho $=0.42 ; 95 \%$ $\mathrm{Cl}=0.32-0.51)$.

\footnotetext{
Comparison of CTS prevalence and its impact on quality of life among preoperative patients and control group

The prevalence of CTS diagnosed by US in preoperative patients was $90(78.94 \%)$ and in controls 46 (36.8\%, $\mathrm{p}<0.0001, \mathrm{OR}=6.4,95 \% \mathrm{Cl}=3.61-11.49)$. Table 3 shows the comparisons of symptoms and signs of CTS in these two groups, and one can note that paresthesias and positive tests for CTS are more common in preoperative patients.
}

The comparison between prevalence of CTS by US and the BCTQ between preoperative patients with the control ones is shown in Table 4, where there are higher values in the preoperative patients.

\section{Comparison of CTS prevalence between pre and postoperative patients}

Table 5 brings the comparison between signs and symptoms of CTS in pre and postoperative patients. There is a postoperative decrease in paresthetic symptoms prevalence, without changes in the prevalence of positive Tinel and Phalen's tests.

When studying the MNA in pre and postoperative patients, we observed a decrease of MNA postoperatively, but the postoperative prevalence of CTS decreased only in individuals who do not performed manual labor.

Table 6 shows the correlation studies between the number of days of the postoperative period and the postoperative weight lost with MNA and the BCTQ.

There was no association of weight loss with the presence of CTS detected by US ( $p=0.73)$, but there was an association of days after surgery with the presence of CTS $(p=0.03)$.

\section{DISCUSSION}

In the present study, we sought to investigate the prevalence of CTS in three different populations: non obese people, prebariatric surgery patients and post bariatric surgery patients, using the calculation of MNA by US as a tool to detect CTS. We adopted the calculation of the MNA

Table 1 - Sample data pairing of 114 bariatric surgery preoperative patients and 90 postoperative bariatric surgery patients.

\begin{tabular}{|c|c|c|c|}
\hline & Preoperative $\mathrm{N}=114$ & Postoperative $\mathrm{N}=90$ & $p$ \\
\hline \multirow[t]{2}{*}{ Gender } & Male $11-9.6 \%$ & Male- $8-8.8 \%$ & \\
\hline & Female $103-90.3 \%$ & Female-81- 91.2\% & $0.87(*)$ \\
\hline \multirow[t]{2}{*}{ Age (years) } & 18 a 66 & 22 a 59 & \\
\hline & Mean $40.86 \pm 11.17$ & Mean $42.00 \pm 10.05$ & $0.38(* *)$ \\
\hline \multirow[t]{2}{*}{ Profission } & Manual labor -84 - 73.6\% & Manual labor - $64-71.11 \%$ & \\
\hline & Non manual labor -30 -26.3\% & Non manual labor $-26-28.8 \%$ & $0.68\left(^{*}\right)$ \\
\hline \multirow[t]{2}{*}{ Raçe } & Caucasian - $88-77.2 \%$ & Caucasian $-75-83.3 \%$ & \\
\hline & African descent - 26-22.8\% & African descent - 15-16.6\% & $0.27(*)$ \\
\hline \multirow[t]{3}{*}{$\mathrm{BMI}\left(\mathrm{Kg} / \mathrm{m}^{2}\right)$} & $34.5-72.31$ & 20.54- 43.73 & $<0.0001(\S)$ \\
\hline & Median de 42.48 & Median de 29.17 & \\
\hline & $\mathrm{IQR}=40.0-46.03$ & $I Q R=25.15-31.69$ & \\
\hline \multirow{3}{*}{$\begin{array}{l}\text { Pre operative BMI } \\
\left(\mathrm{Kg} / \mathrm{m}^{2}\right)\end{array}$} & $34.5-72.31$ & $34.60-67.70$ & $0.83(\S)$ \\
\hline & Median de 42.48 & Median de 42.50 & \\
\hline & $\mathrm{IQR}=40.0-46.03$ & IQR de 39.43-46.8 & \\
\hline
\end{tabular}

$\| Q R=$ interquartile range

$B M I=$ body mass index $\left(^{*}\right)$

- chi square $\left.{ }^{* *}\right)$

- unpaired Student's $T(\S)$

- Mann Whitney 
Table 2 - $\quad$ Clinical manifestations of CTS and MNA measures in each group.

\begin{tabular}{|c|c|c|c|}
\hline & Preoperative $\mathrm{N}=114$ & Postoperative $\mathrm{N}=90$ & Control $\mathrm{N}=125$ \\
\hline \multirow[t]{4}{*}{ Paresthesias } & Both hands: $42-36.8 \%$ & Both hands: $21-23.3 \%$ & Both hands: 32 - 25.6\% \\
\hline & One hand: $25-21.3 \%$ & One hand: $8-8.8 \%$ & One hand: $12-9.6 \%$ \\
\hline & At least one hand: $67-58.7 \%$ & At least one hand: $29-32.2 \%$ & At least one hand: $43-34.4 \%$ \\
\hline & None: $47-41.2 \%$ & None: $61-67.7 \%$ & None: 81 - 64.8\% \\
\hline \multirow[t]{4}{*}{ Dor } & Both hands: $30-26.3 \%$ & Both hands: $19-21.2 \%$ & Both hands: $31-24.8 \%$ \\
\hline & One hand: $6-5.2 \%$ & One hand: $8-8.8 \%$ & One hand: $15-12 \%$ \\
\hline & At least one hand: $36-31.5 \%$ & At least one hand: $27-30 \%$ & At least one hand: $46-36.8 \%$ \\
\hline & None: $78-68.4 \%$ & None: 63 - 70\% & None: $79-63.2 \%$ \\
\hline Positive Tinel and/or & $66-57.8 \%$ & $47-52.2 \%$ & $51-40.8 \%$ \\
\hline \multicolumn{4}{|l|}{ Phalen maneuvers } \\
\hline \multirow[t]{3}{*}{ Right MNA (mm²) } & 4.0 a 25.0 & 4.0 a 22.0 & 4.0 a 15.0 \\
\hline & Median of 11.0 & Median of 10.0 & Median of 7.0 \\
\hline & IQR de 9.0 a 14.0 & IQR de 8.0 a 12.0 & IQR de 7.8 a 9.0 \\
\hline \multirow[t]{3}{*}{ Left MNA $\left(\mathrm{mm}^{2}\right)$} & 4.0 a 24.0 & 5.0 a 19.0 & 4.0 a 15.0 \\
\hline & Median of 10.0 & Median of 9.0 & Median of 7.0 \\
\hline & IQR de 8.0 a 13.25 & IQR de 8.0 a 11.25 & IQR de 6.0 a 8.50 \\
\hline \multirow[t]{3}{*}{ Highest MNA (mm²) } & 4.0 a 25.0 & 5.0 a 22.0 & 4.0 a 15.0 \\
\hline & Median of 12.0 & Median of 10.0 & Median of 8.0 \\
\hline & IQR de 9.0 a 14.0 & IQR de 9.0 a 13.0 & IQR de 6.0 a 10.0 \\
\hline \multirow[t]{3}{*}{ BCTQ } & 19.0 a 82.0 & 19.0 a 61.0 & 19.0 a 72.0 \\
\hline & Median of 25.0 & Median of 22.0 & Median of 19.0 \\
\hline & IQR de 19.0 a 43.0 & IQR de 19.0 a 34.0 & IQR de 26.8 a 33.2 \\
\hline
\end{tabular}

$I Q R=$ interquartile range

$M N A=$ median nerve area

$B C T Q=$ Boston carpal tunnel questionnaire

with the cutoff of $9 \mathrm{~mm}^{2}$. Carvalho et al. ${ }^{16}$ conducted a review about US accuracy for CTS diagnosis and found that the most important US criteria was a MNA between 9 and $10 \mathrm{~mm}^{2}$, as used by us. They also concluded that US can be used as a first-line test for CTS and it can be applied in daily clinical practice, with $1 \mathrm{~b}$ evidence level. A metaanalysis by Tai et al. ${ }^{22}$ also indicated that this is the cutoff with the highest diagnostic accuracy. US is considered to have equal capability to detect CTS as electromyography studies, usually considered the gold standard method for $\mathrm{CTS}^{23}$. Thus, US may be used as a first line tool, reducing the need for electromyography examinations ${ }^{16}$ and saving the latter for symptomatic patients with negative US.

We used the BCTQ to measure the degree of symptoms, as well as difficulties to use the hands, problems that impact in patient's quality of life. This tool has ability

Table 3 - Comparison of clinical data (signs and symptoms) of CTS between preoperative patients and the control group.

\begin{tabular}{|c|c|c|c|}
\hline & Preoperative $\mathrm{N}=114$ & Control $\mathrm{N}=125$ & $P$ \\
\hline \multirow[t]{4}{*}{ Paresthesias } & Both hands $-42-36.8 \%$ & Both hands - 32-25.6\% & $0.0003(*)$ \\
\hline & One hand - 25- $21.3 \%$ & One hand - 12-9.6\% & \\
\hline & At least one hand $=67-58.7 \%$ & At least one hand = 43-34.4\% & \\
\hline & None - $47-41.2 \%$ & None - 81-64.8\% & \\
\hline \multirow[t]{4}{*}{ Pain } & Both hands - $30-26.3 \%$ & Both hands - 31-24.8\% & 0.39 \\
\hline & One hand - $6-5.2 \%$ & One hand - 15-12\% & \\
\hline & At least one hand $=36-31.5 \%$ & At least one hand $=46-36.8 \%$ & \\
\hline & None - $78-68.4 \%$ & None - $79-63.2 \%$ & \\
\hline Tinnel and/or Phallen manouvers & $66-57.8 \%$ & $51 / 125=40.8 \%$ & $0.0083(*)$ \\
\hline
\end{tabular}

(*) comparative data taken of "at least one hand".

All the tests=chi square 
Table 4 - Comparison of carpal tunnel syndrome by ultrasonography and boston carpal tunnel questionnaire results between the preoperative group and control one.

\begin{tabular}{|c|c|c|c|}
\hline & Preoperative $\mathrm{N}=114$ & Control $\mathrm{N}=125$ & $\mathbf{P}$ \\
\hline Right MNA $\left(\mathrm{mm}^{2}\right)$ & $\begin{array}{l}4.0-25.0 \\
\text { Median of } 11.0 \\
\mathrm{IQR}=9.0-14.0\end{array}$ & $\begin{array}{l}\text { 4.0-15.0 } \\
\text { Median of } 7.0 \\
\text { IQR de } 7.8-9.0\end{array}$ & $<0.0001\left(^{*}\right)$ \\
\hline Left MNA $\left(\mathrm{mm}^{2}\right)$ & $\begin{array}{l}\text { 4.0-24.0 } \\
\text { Median of } 10.0 \\
\text { IQR de } 8.0-13.25\end{array}$ & $\begin{array}{l}\text { 4.0-15.0 } \\
\text { Median of } 7.0 \\
\text { IQR de } 6.0-8.50\end{array}$ & $<0.0001\left(^{*}\right)$ \\
\hline Bigger MNA $\left(\mathrm{mm}^{2}\right)$ & $\begin{array}{l}\text { 4.0-25.0 } \\
\text { Median of } 12.0 \\
\text { IQR de } 9.0-14.0\end{array}$ & $\begin{array}{l}\text { 4.0-15.0 } \\
\text { Median of } 8.0 \\
\text { IQR de } 6.0-10.0\end{array}$ & $<0.0001\left(^{*}\right)$ \\
\hline BCTQ & $\begin{array}{l}19 \text { a } 82.0 \\
\text { Median of } 25.0 \\
\text { IQR }=19.0-43.0\end{array}$ & $\begin{array}{l}\text { 19.0-72.0 } \\
\text { Median of } 19.0 \\
\text { IQR de } 26.8-33.2\end{array}$ & $0.0004\left(^{*}\right)$ \\
\hline
\end{tabular}

(*) Mann Whitney test

$I Q R=$ interquartile range

$M N A=$ median nerve area

$B C T Q=$ Boston carpal tunnel questionnaire

to assess the course of the CTS and the effectiveness of treatment, whether conservative or surgical ${ }^{3}$. Levine et al emphasize the usefulness of BCTQ to judge severity and functional impairment in patients with CTS, stressing that this instrument is easy to implement, which favors its widespread use by researchers. Leite et al. ${ }^{5}$ conducted a systematic review to assess the psychometric properties of
BCTQ and concluded that it is a good instrument, with great validity, reliability and responsiveness.

In the present study, BCTQ scores between preoperative patients and controls were different, with higher values in the preoperative group, showing that CTS has greater impact in obese people. Nevertheless it was not possible to show any difference between patients in

Table 5 - Comparison of the median nerve area by ultrasonography and boston carpal tunnel questionaire results between pre and post bariatric surgery patients.

\begin{tabular}{|c|c|c|c|}
\hline & Preoperative $\mathrm{N}=114$ & Postoperative $\mathrm{N}=90$ & $P$ \\
\hline Right MNA $\left(\mathrm{mm}^{2}\right)$ & $\begin{array}{l}4.0 \text { a } 25.00 \\
\text { Median of } 11.0 \\
\text { IQR de } 9.0 \text { a } 14.0\end{array}$ & $\begin{array}{l}4.0 \text { a } 22.0 \\
\text { Median of } 10.0 \\
\text { IQR de } 8.0-12.0\end{array}$ & $0.05(\#)$ \\
\hline Left MNA (mm²) & $\begin{array}{l}4.0 \text { a } 24.0 \\
\text { Median of } 10.0 \\
\text { IQR de } 8.0 \text { a } 13.25\end{array}$ & $\begin{array}{l}5.0 \text { a } 19.0 \\
\text { Median of } 9.0 \\
\text { IQR de } 8.0 \text { a } 11.25\end{array}$ & $0.06(\#)$ \\
\hline Bigger MNA $\left(\mathrm{mm}^{2}\right)$ & $\begin{array}{l}4.0 \text { a } 25.0 \\
\text { Median of } 12.0 \\
\text { IQR de } 9.0-14.0\end{array}$ & $\begin{array}{l}5.0-22.0 \\
\text { Median of } 10.0 \\
\text { IQR de } 9.0-13.0\end{array}$ & $0.04\left(^{*}\right)$ \\
\hline Patients with CTS & $90 / 114=78.9 \%$ & $69 / 90=76.6 \%$ & $0.69^{(*)}$ \\
\hline $\begin{array}{l}\text { Patients with CTS and } \\
\text { manual labor }\end{array}$ & $67 / 84-79.7 \%$ & $43 / 53-81.1 \%$ & $0.84\left(^{*}\right)$ \\
\hline $\begin{array}{l}\text { Patients with CTS and } \\
\text { non manual labor }\end{array}$ & $23 / 29-79.3 \%$ & $21 / 37-56.5 \%$ & $0.05\left(^{*}\right)$ \\
\hline BCTQ & $\begin{array}{l}19 \text { a } 82.0 \\
\text { Median of } 25.0 \\
\text { IQR de } 19.0-43.0\end{array}$ & $\begin{array}{l}\text { 19.0- } 61.0 \\
\text { Median of } 22.0 \\
\text { IQR de 19.0-34.0 }\end{array}$ & $0.070(\#)$ \\
\hline
\end{tabular}

(\#)- Mann Whitney(*)

- Chi square

CTS = carpal tunnel syndrome

$M N A=$ median nerve area

$B C T Q=$ Boston carpal tunnel questionnaire 
Table 6 - Correlation between weight loss $(\mathrm{kg})$ and number of postoperative days with the MNA and with boston carpal tunnel questionnaire results.

\begin{tabular}{lccc}
\hline Weight lost $(\mathrm{Kg})$ & 4.0 a 130.0 & mean of $39.09 \pm 17.39 \mathrm{~kg}$ & $\mathrm{P}$ \\
& Spearman's Rho & $95 \%$ IC & 0.53 \\
Bigger MNA & -0.066 & $"-0.27-0.14 "$ & 0.55 \\
BCTQ & -0.062 & $"-0.27-0.15 "$ & \\
\hline Post operatively days: & 9 e 4745 & mean of 405 IQR of 181.5 a 675 days & \\
& Spearman's Rho & $95 \%$ IC P & 0.014 \\
Bigger MNA & 0.25 & "0.04 a $0.44 "$ & 0.32 \\
BCQT & 0.10 & $"-0.11$ a $0.31 "$ & \\
\hline
\end{tabular}

$M N A=$ median nerve area

$B C T Q=$ Boston carpal tunnel questionnaire

the preoperative group compared with the postoperative one, despite of a mean weigh loss of $39 \mathrm{~kg}$. It can therefore be concluded that obesity is associated with CTS, but weight loss in bariatric surgery is not sufficient to improve its repercussions in daily life. The higher prevalence of CTS in obese individuals is already well known in the literature ${ }^{6-13}$. Similarly, Moghtaderi et al. ${ }^{8}$ conducted a case-control study examining risk factors for CTS and demonstrated that BMI, age and anthropometric data of the wrist were higher in patients with CTS than in controls. Interestingly, Kouyoumdjian et al. ${ }^{12}$, although having found an association between CTS and increased BMI, could not establish an association between CTS severity and BMI, as happened in the postoperative group.

As previously mentioned, there are at least two hypotheses to explain the high prevalence of CTS in obese people. One is the physical presence of fatty tissue in the carpal tunnel, causing mechanical compression to the nerve root. The other is the occurrence of microvascular disturbances associated with the atherogenesis caused by obesity. In the second hypothesis, the CTS symptoms would not respond to weight loss, as was found at present. Corroborating these findings, Kurt et al. ${ }^{11}$ studied CTS in 92 obese patients, who underwent a three-month dietary program for weight loss, and found no changes in nerve conduction studies, signs or symptoms after that intervention. Also, Shiri et al. ${ }^{13}$ demonstrated an association of CTS with dyslipidemia, hypertension and cardiac arrhythmia in individuals between 30 and 34 years of age, and with coronary artery disease, valvular heart disease and carotid intimal thickness in subjects aged 60 years or more. Therefore, the presence of CTS in an obese person may be a warning sign for cardiovascular morbidity and mortality, as it seems to reflect the status of atherosclerosis. In this context, it is also important to remember that adipose tissue is a multifunctional organ that is not restricted to the accumulation of energy, but also exerts endocrine and immune functions. Adipocytes release molecules such as interleukin-6, tumor necrosis factor alpha and leptin, which may act by promoting local and systemic inflammation.
The biological activities of interleukin- 6 contribute to the progression of the atheromatous plaque ${ }^{24}$. In the study of Valezi et al. ${ }^{25}, 20$ patients with morbid obesity that underwent bariatric surgery were studied regarding inflammatory markers, indicators of oxidative stress and antioxidant defense. They demonstrated the highest level of these biomarkers in the preoperative patients and subsequent decline in the postoperative period. These findings strengthened the role of adipose tissue as a chronic inflammation agent. Appachi et al. ${ }^{26}$ conducted a cohort study with 45 patients before and six months after bariatric surgery, and observed signs of increased adiponectin and decreased leptin/adiponectin ratio in the pre-operatory phase. This is representative of a pro-inflammatory profile in patients with morbid obesity, which is associated with atherogenesis and cardiovascular risk. These atherogenesisfavoring inflammatory components may be implicated in the pathogenesis of CTS by microvascular injury. Nevertheless, there are no data in the literature on the inflammatory profile in pre and post bariatric surgery patients that concurrently analyzes the presence of CTS. This is a suggestion for future studies. The present results corroborate the microvascular hypothesis in CTS pathogenesis, but a combination with mechanical factors cannot be ruled out.

We found an association between postoperative days and MNA values, and between the former and CTS prevalence. This may also be explained by changes in inflammatory markers after surgery. Valezi et al. ${ }^{25}$ demonstrated a fall in C-reactive protein levels in postoperative patients, which progressively decreased from two to 12 months after bariatric surgery. This enables to infer that the postoperative time was crucial to the reduction of the obesity pro-inflammatory state. This information is extremely important when one observes that, in the present study, although the prevalence of postoperative CTS has not changed, the classic symptoms of the disease (paresthesia) and values of MNA have decreased. It is possible that with a study of longer duration one may find a significant difference in the postoperative prevalence of CTS. It would also be interesting to study the findings 
associate with clinical symptoms, pro-inflammatory markers and assessment of CTS by US in pre and postoperative patients, at different times of evolution. Studies encompassing all these topics were not found in the literature, but this is a speculation that, if answered, can bring data to elucidate the cause of CTS in obesity.

Another aspect which may be infered from the present study is the role of intervenient factors, such as labor, in the prevalence of CTS in obese people. The current results show influence of manual labor in the occurrence of CTS only in postoperative patients but not in the preoperative ones. Taking this variable into account, one can interpret the present result in the following way: no difference of CTS was observed in the preoperative group among non- manual vs. manual workers, because the severe obesity dominated the scenario and obscured other factors. Postoperatively, when obesity ceased, the labor factor became more important.

\section{CONCLUSION}

There is higher prevalence of CTS in obese patients that are candidates for bariatric surgery when compared with controls. Also, there was no evidence in the present sample of a significant difference in the general prevalence of CTS in post bariatric surgery patients compared with the preoperative group.

\title{
R E S U M O
}

\begin{abstract}
Objetivo: verificar a prevalência da STC em pacientes obesos candidatos à cirurgia bariátrica comparada com a prevalência em indivíduos não obesos e em pacientes já submetidos ao procedimento cirúrgico para verificar se as medidas de perda de peso influem na prevalência e gravidade dos sintomas. Métodos: três grupos de indivíduos foram estudados: 1) candidatos à cirurgia bariátrica (pré-operatório); 2) já submetidos ao tratamento cirúrgico bariátrico (pós-operatório) e 3) grupo controle. Foram coletados dados demográficos e clínicos referentes à síndrome do túnel do carpo. Foi realizada ultrassonografia para medição da área da secção transversa do nervo mediano para o diagnóstico da síndrome. Resultados: foram incluídos 329 indivíduos (114 no grupo préoperatório, 90 no grupo pós-operatório e 125 controles). Houve maior prevalência de parestesias quando se comparou o grupo préoperatório com o controle $(p<0,00001)$. Houve diminuição das parestesias $(p=0,0002)$ e da área da secção transversa do nervo mediano ( $p=0.04)$ nos pacientes do pós-operatório, mas não houve diferença significativa na prevalência geral da síndrome do túnel do carpo. Foi observada diferença significativa entre os grupos pré e pós-operatório $(p=0,05)$ nos indivíduos que realizavam trabalho não manual. Conclusão: houve maior prevalência da síndrome do túnel do carpo entre o grupo pré-operatório comparado com o controle, mas não se observou diferença significativa entre os grupos pré e pós-operatório no geral. Houve diferença entre os grupos pré e pós-operatório dentre os trabalhadores não manuais.
\end{abstract}

Descritores: Obesidade. Síndrome do Túnel do Carpo. Ultrassonografia. Cirurgia Bariátrica.

\section{REFERENCES}

1. LeBlanc KE, Cestia W. Carpal tunnel syndrome. Am Fam Physician. 2011;83(8):952-8.

2. Aroori S, Spence RA. Carpal tunnel syndrome. Ulster Med Soc. 2008;77(1):6-17

3. Levine DW, Simmons BP, Koris MJ, Daltroy LH, Hohl GG, Fossel AH, et al. A self-administered questionnaire for the assesment of severity of symptoms and functional status in carpal tunnel syndrome. J Bone Joint Surg Am. 1993;75(11):1585-92.

4. Campos CC, Manzano GM, Andrade LB, Castelo Filho A, Nóbrega JAM. Tradução e validação do questionário de avaliação de gravidade dos sintomas e do estado funcional na síndrome do túnel do carpo. Arq Neuro-Psiquiatr. 2003;61(1):51-5.

5. Leite JC, Jerosch-Herold C, Song F. A systematic review of the psychometric properties of the Boston Carpal Tunnel Questionnaire. BMC Musculoskelet Disord. 2006;7:78.

6. Sharifi-Mollayousefi A, Yazdchi-Marandi M, Ayramlou H, Heidari $P$, Salavati A, Zarritan S, et al. Assessment of body mass index and hand anthropometric measurements as independent risk factors for carpal tunnel syndrome. Folia Morphol. 2008;67(1):36-42.

7. Lam N, Thuston A. Association of obesity, gender, age and occupation with carpal tunnel syndrome. Aust N Z J Surg. 1998;68(3):190-3
8. Moghtaderi A, Izadi S, Sharafadinzadeh N. An evaluation of gender, body mass index, wrist circumference and wrist ratio as independent risk factors for carpal tunnel syndrome. Acta Neurol Scand. 2005;112(6):375-9.

9. Mattioli S, Baldasseroni A, Bovenzi M, Curti S, Cooke RM, Campo $G$, et al. Risk factors for operated carpal tunnel syndrome: a multicenter population-based case-control study. BMC Public Health. 2009;9:343

10. Balci K, Utku U. Carpal tunnel syndrome and metabolic syndrome. Acta Neurol Scand. 2007;116(2):113-7.

11. Kurt S, Kisacik B, Kaplan Y, Yildirim B, Etikan I, Karaer H. Obesity and carpal tunnel syndrome: is there a causal relationship? Eur Neurol. 2008;59(5):253-7

12. Kouyoumdjian JA, Morita MD, Rocha PR, Miranda RC, Gouveia GM. Body mass index and carpal tunnel syndrome. Arq Neuropsiquiatr. 2000;58(2A):252-6

13. Shiri R, Heliövaara M, Moilanen L, Viikari J, Liira H, Viikari-Juntura E. Associations of cardiovascular risk factors, carotid intimamedia thickness and manifest atherosclerotic vascular disease with carpal tunnel syndrome. BMC Musculoskelet Disord. 2011;12:80

14. Turrini E, Rosenfeld A, Juliano Y, Fernandes ARC, Natour J. Diagnóstico por imagem do punho na síndrome do túnel do carpo. Rev Bras Reumatol. 2005;45(2):81-3. 
15. Lee JC, Healy JC. Normal sonographic anatomy of the wrist and hand. Radiographics. 2005;25(6):1577-90.

16. Carvalho KMD, Soriano EP, Carvalho MVD, Mendoza CC, Vidal HG, Araújo ABVL. Nível de evidência e grau de recomendação dos artigos sobre a acurácia diagnóstica da ultrassonografia na síndrome do túnel do carpo. Radiol Bras. 2011;44(2):85-9.

17. El Miedany YM, Aty SA, Ashour S. Ultrassonography versus nerve conducting study in patients with carpal tunnel syndrome: substantive or complementary tests? Rheumatology. 2004;43(7):887-95.

18. Alfonso C, Jann S, Massa R, Torreggiani A. Diagnosis, treatment and follow-up of the carpal tunnel syndrome: a review. Neurol Sci. 2010;31(3):243-52.

19. Gastrointestinal surgery for morbid obesity: National Institutes of Health Consensus Development Conference Statement. Am J Clin Nutr 1992; 55(2): 615-19

20. Ibrahim I, Khan WS, Goddard N, Smitham P. Carpal tunnel syndrome: a review of the recent literature. Open Orthop J. 2012;6:69-76.

21. Alves MPT, Fonseca COP, Granjeiro JM, Souza PRG, Tzirulnik M Síndrome do túnel do carpo: estudo comparativo entre a medição ultrassonográfica e cirúrgica do nervo mediano nos casos moderados e severos da doença. Radiol Bras. 2013;46(1):23-9.

22. Tai TW, Wu CY, Su FC, Chern TC, Jou IM. Ultrassonography for diagnosing carpal tunnel syndrome: a meta-analysis of diagnostic test accuracy. Ultrasound Med Biol. 2012;38(7):1121-8.
23. Guan J, Ji F, Chen W, Chu H, Lu Z. Sonographic and electrophysiological detection in patients with carpal tunnel syndrome. Neurol Res. 2011;33(9):970-5.

24. Moulin CM, Marguti I, Peron JPS, Rizzo LV, Halpem A. Impact of adiposity on immunological parameters. Arq Bras Endocrinol Metab. 2009;53(2):183-9.

25. Valezi AC, Cabrera EJ, Delfino VDA, Barbosa DS, Mali Júnior J, Menezes MA. Derivação gástrica em Y-de-Roux e a atividade inflamatória do tecido adiposo. Rev Col Bras Cir. 2011;38(3):1616.

26. Appachi S, Kelly KR, Schauer PR, Kirwan JP, Hazen S, Gupta M, et al. Reduced cardiovascular risk following bariatric surgeries is related to a partial recovery from "adiposopathy". Obes Surg. 2011;21(12):1928-36.

Received 06/01/2014

Accepted for publication 05/03/2014

Conflicts: none.

Fundings: Coordenação de Aperfeiçoamento de Pessoal de Nível Superior (CAPES)

\section{Correspondence:}

Adham do Amaral e Castro

E-mail: adham.castro@gmail.com 